\title{
Izborno zakonodavstvo u Bosni i Hercegovini: problemi, potrebe i mogućnosti
}

\author{
Elvis Fejzić \\ Vanredni profesor Fakulteta političkih nauka \\ Univerziteta u Sarajevu \\ elvis.fejzic@fpn.unsa.ba
}

\begin{abstract}
Sažetak: Izborni sistem u postdejtonskoj Bosni i Hercegovini je kompliciran i nerijetko producira političke blokade u formiranju i funkcioniranju vlada na različitim nivoima vlasti. $\mathrm{Na}$ osnovu detaljne kritičke analize i uvida u proporcionalni izborni sistem, model glasanja i sistem finansiranja političkih partija u bosanskohercegovačkoj praktičnoj politici, moguće je detektirati ključna ograničenja u postojećem izbornom zakonodavstvu. Navedena saznanja trebalo bi obavezno uzeti u obzir kod predlaganja novih izmjena u izbornoj proceduri, ako se pretendira da reforma izbornog zakona korespondira sa pronalaženjem funkcionalnijeg modela za biranje demokratske vlasti. Međutim, da bi se takav reformski zahvat realizirao bosanskohercegovačke političke elite trebale bi prethodno pristati da svoje partikularne interese podrede općem interesu demokratske zajednice, jer bez toga nije moguće osigurati harmoniziran politički okvir i neometano formiranje demokratske vlasti u postizbornom periodu.
\end{abstract}

Ključne riječi: izbori, zakonodavstvo, izborni sistem, političke institucije, političke partije, građani, vlada, političko predstavljanje

\section{Uvodni kontekst}

Izborno zakonodavstvo Bosne i Hercegovine ima redukcionistički karakter, sa aspekta političke jednakosti i temeljnih političkih prava, jer uzurpira i minimizira participacijske mogućnosti građana, ali i etnonacionalnih skupina. Najveći problem predstavlja nefunkcionalno rješenje u pogledu mogućnosti političkog izbora, koji građani mogu ili u nekim slučajevima ne mogu napraviti, kao pripadnici različitih etničkih grupa, na cijeloj teritoriji države Bosne i Hercegovine. Prema tome, zbog hegemonističkog statusa etničkog predstavljanja, koje je ukorijenjeno u ustavu i izbornom zakonu te nadređeno predstavljanju građana, pojedinci u bosanskohercegovačkoj postdejtonskoj političkoj praksi ne mogu realizirati puno pravo na političku jednakost. Iako je evidentno da je potrebno revidirati i korigirati izborno zakonodavstvo, kako bi bili zadovoljeni normativni zahtjevi pluralističke demokratije i temeljne 
atribucije narodnog suvereniteta, to će, po svemu sudeći, biti teško realizirati u postojećem političkom kontekstu, koji dominantno reguliraju zagovornici etnokratske vizije politike, čiji ni novi korektivni prijedlozi ne odstupaju značajno od navedene političke koncepcije. (prema: Zakon o izmjenama Izbornog zakona Bosne i Hercegovine, 2020, čl. 1. i 2.) Tako da dosadašnje izmjene izborne regulative u Bosni i Hercegovini uglavnom nisu imale funkcionalan karakter, već su napravljene i donesene pod političkim pritiskom i u iznuđenim političkim dogovorima koji su distancirani od temeljnih principa pluralističke demokratije.

Slobodni izbori i legalistička izborna procedura, barem je to tako u normativnim predstavama o demokratskom izbornom procesu, osiguravaju i uvjetuju legitimno političko predstavljanje, bez čega demokratija ne može opstati kao forma i režim političke vladavine, niti se može osigurati neometano cirkuliranje i nadmetanje političkih elita - oko različitih interesa i problema - što je osnovna pretpostavka za postojanje političkog pluralizma kao multiverzuma diferentnih svjetonazora. Izborna procedura može uključivati različite nivoe vlasti koji podliježu izbornom procesu i selekciji, što u značajnoj mjeri zavisi i od prirode ustavnog i političkog sistema u nekoj državi. Ipak, učestalo glasanje i dinamično participiranje građana na različitim izborima u demokratskim državama ,... nosi opasnosti. Jedna je zamor glasača koji vodi do pada interesovanja, izlaznosti i kvaliteta selekcije.“ (Hague, Harrop, 2014: 270) Stoga, potrebno je u demokratskim državama, pa čak i onim koje imaju izražen tranzicijski karakter kao Bosna i Hercegovina, funkcionalno podesiti dinamiku izbornih perioda, kako učestalo izborno biranje ne bi destimuliralo građanski aktivitet i političku participaciju građanstva. Iako postoji više vrsta glasačkog prava treba istači da samo opće pravo glasa u savremenim demokratijama osigurava građanima pravo na punu političku participaciju, zbog čega se smatra temeljnim obilježjem liberalno-demokratskih i pluralističkih režima vlasti.

Građani svoje biračko pravo, u pravilu, mogu realizirati javnim i tajnim glasanjem. Ipak, javno i neposredno glasanje puno je primjerenije lokalnim manifestacijama demokratske volje, a realizira se putem instituta direktne demokratije u lokalnoj politici, koji se koriste obično kao dopunski mehanizam predstavničke demokratije. (Kaningam, 2003) S druge strane, glasanje na referendumu - predstavlja temeljni instrument direktne demokratije - je tajno i nerijetko može imati reduciran demokratski potencijal, a posebno kada se uloga i svrha ,... referendumske demokratije u modernoj politici reducira... na funkciju dopunskog sredstva za donošenje političkih odluka, odnosno na 
prethodni mehanizam za legitimiranje odluka... koje donosi politička vlast.“ (Fejzić, 2016: 21) Osim što izbori moraju biti slobodni, kako bi se osigurala neometana participacijska mogućnost zainteresiranog građanstva tajnim glasanjem, oni moraju imati i takmičarski karakter, jer bez toga nije moguće sačuvati heretički i pluralistički duh demokratske politike putem koje se producira opća volja. U navedenom kontekstu političke partije i njihovi kandidati na izborima predstavljaju funkcionalnu sponu između praktičnih zahtjeva građanstva i etabliranja legitimne državne vlasti, koja kroz institucionalnu proceduru stvara politički okvir za implementiranje opće volje.

\section{Izborni sistem u Bosni i Hercegovini: atribucije i problemi}

Temeljne funkcije izbora u tranzicijskoj bosanskohercegovačkoj stvarnosti, zbog karaktera političke vlasti i limitiranog ustavno-zakonskog okvira, ne mogu biti do kraja realizirane u političkoj praksi, zbog čega izbori u ovom političkom kontekstu nemaju i ne ostvaruju svoju osnovnu svrhu koja treba korespondira sa zahtjevima poliarhijskih režima vlasti. S tim u vezi, trebalo bi detaljno, dubinski i kritički analizirati i na temelju toga funkcionalno rekonstruirati sva pravila za upravljanje izborima unutar izbornog sistema $\mathrm{u}$ Bosni i Hercegovini, a posebno ona koja se odnose na strukturu glasačkih listića i broj stranačkih kandidata, izbornu formulu, tj. način transformiranja glasova u mandate i, na kraju, svrhovitost teritorijalne podjele na postojeće izborne jedinice. (prema: Hague, Harrop, 2014) Bez takve funkcionalne korekcije, zapravo, sve osnovne funkcije izbora u bosanskohercegovačkoj praktičnoj politici ostat će u velikoj mjeri reducirane, a prije svega bit će i dalje defektno predstavljanje volje političkog naroda koju tvori i generira bosanskohercegovačko građanstvo kroz izbornu proceduru. Imajući u vidu značaj političkog predstavništva u savremenoj demokratskoj politici ističe se da ,... otkad je nacija proglašena 'suverenom', zastupništvo mijenja svoj smisao. Postaje 'opće' i proizlazi iz ustava. Od individualnih zastupnika onih koji su ih odredili, izabranici postaju opći zastupnici nacije, shvaćene kao kolektivna i apstraktna cjelina. U novom i sada već klasičnom značenju termina, 'zastupnik' je osoba ili tijelo koji po ustavu ima 'pravo nešto htjeti' za naciju. ... Mandat javnog prava je opći, slobodan, neopoziv i pretpostavlja se da se uvijek provodi u skladu s voljom opunomoćitelja.“ (Prelot, 2002: 92) Prema tome, sistem političkog predstavljanja, kao osnova demokratske politike, nije u bosanskohercegovačkoj političkoj praksi koncipiran, osmišljen, 
normiran i definiran u skladu sa principima političkog liberalizma, egalitarizma i narodnog suvereniteta, što ometa i diskreditira efikasnu političku participaciju građanstva i općenito reprezentiranje interesa građana u javnoj sferi. Štaviše, moguće je konstatirati da: „Legitimacioni lanac... ne polazi od apstraktnog građanina koji svoje izborno pravo može koristiti kao apsolutno važeći glas na cijeloj državnoj teritoriji - nego od fingiranih etnija: svi građani Republike Srpske su na državnom nivou uvijek legitimirani kao etnički Srbi, iz Federacije kao Bošnjaci i Hrvati. Izabrani predstavnici etnija usmjeravaju cjelokupan parlamentarni život zakonodavnim vetom, tako da vršenje državnih zadataka uvijek počiva na etničkoj volji.“ (Šarčević, 2009: 78) U takvim političkim uvjetima građani ne mogu osigurati i kreirati djelotvoran sistem predstavljanja svojih političkih interesa, jer nisu dominantan i ključni akter u etnokratiziranoj i kolektiviziranoj praktičnoj politici, niti mogu neometano vršiti suverenu vlast i prenositi pravo na legitimno vladanje, putem izborne procedure, na svoje političke predstavnike. Drugim riječima, takav režim vladavine ima obilježja zarobljenog demokratskog procesa.

No, i druge izborne funkcije su značajno ograničene u postdejtonskoj Bosni i Hercegovini, jer se usporeno i sa puno problema formiraju postizborne koalicione predstavničke vlade, birači ne prolaze prethodno kroz adekvatne procese političke socijalizacije, politička regrutacija članstva odvija se prema pravilima iznuđene socijalne promocije i nepotizma, stranačke partokratske strukture imaju nerijetko direktan nadzor nad praktičnom politikom, zbog hegemonijske pozicije etnokratske vladavine cirkuliranje političkih elita odvija se otežano i producira elitističke manifestacije u političkoj praksi te, na kraju, izabrana državna vlast se suočava sa fenomenom reduciranog legitimiteta koji je, u pravilu, uvjetovan sterilnim koalicijskim politikama i nefunkcionalnim odnosom prema političkim obećanjima. Tako da se postdejtonska bosanskohercegovačka politika suočava, pored klasičnih ograničenja demokratske vladavine i izborne politike što se odnose na elitizaciju i plutokratizaciju političkog procesa te komercijaliziranje izbornog takmičenja, sa nekim posebnim problemima i nedostacima koji su specifični i markiraju tranzicijske, nove i postsocijalističke režime vlasti, ali i etnički heterogene političke zajednice. U jednom od političkih narativa u savremenoj politologiji, u kojem se ukazuje na izražene elitističke dimenzije demokratske politike, akcentiraju se sljedeće atribucije protudemokratske vlasti: „Biračko telo može da odluči koja će elita da vlada, ali nije u stanju da promeni okolnost da je vlast uvek u rukama neke elite. ... U stvari, izborno takmičenje dovodi do stvaranja političkog tržišta na kome se političari ponašaju kao preduzetnici okrenuti osvajanju vlasti, 
a birači kao potrošači koji glasaju za partiju čija politika najbolje odražava njihove težnje.“ (Hejvud, 2004: 158) Ekspanzivna plutokratizacija i komercijalizacija političke sfere implikacija su direktnih i indirektnih uticaja organiziranih korporacijskih interesa i skupina na demokratski i izborni proces $\mathrm{u}$ savremenim državama. Naime, političke stranke koje se takmiče na izborima i bore za osvajanje vlasti u neoliberalnom političkom okruženju žele i nastoje da privuku ,... financijske fondove velikih tvrtki... Milijunaši nisu zamijenili članarine i sindikate, jer si stranka ne može dopustiti da odustane od bilo kojeg dijela financiranja, sad kada su izbori postali toliko skupi. No aktivisti koje mogu privući nove i bogate donatore iz poslovnog sektora mogu demotivirati druge podupiratelje.“ (Crouch, 2007: 81) Imajući navedeno u vidu takmičenje političkih stranaka u izbornom procesu sve više asocira na aukciju, kupovinu uticaja i demonstriranje komercijalizirane političke moći, a sve manje na svjetonazorsku i programsku utakmicu partijskih aktera, koja je skoncentrirana oko kvalitetnih političkih rješenja i odgovora na zahtjeve građanstva.

S tim u vezi, sistem finansiranja političkih partija je u velikoj mjeri delegitimiran, prije svega zbog privilegirane uloge privatnih finansijera predizbornih kampanja, pa se sve učestalije sumnja u pluralistički i takmičarski karakter izbora, ali i demokratske rezultate izborne selekcije. Sa ovim problemima suočavaju se i razvijene, ali i tranzicijske demokratije, poput bosanskohercegovačke postsocijalističke demokratije, koja nema efikasno uređenu i dostatnu regulativu u sferi finansiranja političkih stranaka. (prema: Zakon o finansiranju političkih stranaka, 2012) Štaviše, ni političke korekcije koje su naknadno realizirane u ovom segmentu bosanskohercegovačke partijske i izborne politike, nakon donošenja zakona o finasiranju političkih stranaka, nisu znatno djelotvornije uredile ovu ključnu oblast demokratske politike od koje direktno zavisi legalnost takmičenja političkih stranaka i legitimnost državne vlasti koja nastaje kao implikacija navedenog političkog natjecanja. (prema: Zakon o izmjenama i dopunama Zakona o finansiranju političkih stranaka, 2016) Prema tome, na takav način dovodi se u pitanje ključni mehanizam demokratske politike koji se zasniva na sljedećoj tvrdnji: „Moderna društva osuđena su da se oslanjaju isključivo na 'volju naroda' onako kako proističe iz jednakih i slobodnih prava participacije kada se radi o osnovi njihovog sopstvenog opravdanja, odnosno kao na konačan agens i podsticaj za donošenje kolektivno obavezujućih odluka.“ (Ofe, 1999: 134) Volja naroda koja ne nastaje kao rezultat istinske političke participacije građanstva, u osnovi, nema demokratski potencijal, jer se ona ne može stvarati kupovinom uticaja, 
mitom i korupcijom. U demokratskim režimima vlasti nerijetko se događaju problemi, pa, čak, i afere u sferi finansiranja političkih partija, zbog čega treba apostrofirati sljedeće: „U demokratijama, korupcionaški skandali su često povezani sa finansiranjem političkih kampanja. Neke zemlje imaju malo birokratske korupcije ali su opterećene korumpiranim političkim procesom. Međutim, novac se ne može potpuno eliminisati iz politike. Izbori se moraju nekako finansirati i bogate interesne grupe će biti voljne da plate račun. Finansijski pritisci daju političarima podsticaj da prihvate mito, radeći tako protiv antikorupcijskih efekata slobodnih izbora." (Rouz-Ejkerman, 2007: 144) Stoga, samo adekvatna regulativa o finansiranju političkih partija može osigurati potrebne uvjete za neometano i demokratsko nadmetanje stranačkih elita u izbornom procesu, bez čega nije moguće selekcionirati vlast u skladu sa voljom naroda.

Izborni sistemi prema svojoj tipologiji mogu biti zasnovani na većinskom, proporcionalnom i mješovitom sistemu. (Conley, 2001; Franklin, Wlezien, 2002; Hejvud, 2004; Renwick, 2010) U tom smislu postoje razlike oko načina izgradnje i stvaranja većinske političke volje kod svih navedenih tipova izbornog sistema. Izborni sistemi sa relativnom i apsolutnom većinom u demokratskim državama su se tokom dvadesetog stoljeća reformirali u pravcu prihvatanja normi i pravila proporcionalnog sistema - takve okolnosti odgovarale su u većini slučajeva i liberalima, i konzervativcima, ali i različitim socijalističkim reprezentacijama - koji je nerijetko sklon produciranju koalicionih vlada. Bosna i Hercegovina kao postsocijalistička država, također, prihvatila je pravila proporcionalnog izbornog sistema u izbornom zakonodavstvu - što je razumljivo imajući u vidu njenu heterogenu i složenu etnonacionalnu, religijsku i teritorijalnu strukturu - koji je dopunjen biračkim preferencijalnim mogućnostima izbora na ponuđenim stranačkim listama. (Detaljnije o specifičnostima izbornog sistema u Bosni i Hercegovini informirati se u: Bieber, 2006) Ipak, bitno je konstatirati da svaki od navedenih modela ima izražene prednosti i ograničenja, pa u kontekstu njihove funkcionalnosti i reprezentativnosti nije moguće postići saglasnost istraživača u politologiji koji se, uzmimo, bave izborima, izbornim politikama i sistemima. Ono što je neizostavna obaveza državne vlasti u Bosni i Hercegovini jeste da čim prije treba korigirati i izmijeniti postojeće izborno zakonodavstvo, a u skladu sa donesenim presudama Evropskog suda za ljudska prava i domaćih sudova, kako bi građani imali osigurano puno političko pravo i jednakost na cijeloj teritoriji države Bosne i Hercegovine i kako bi, uz to, adekvatno bila promovirana, zaštićena i reprezentirana prava nacionalnih skupina i manjinskih zajednica, u kontekstu 
prava na personalnu, kulturnu i funkcionalnu autonomiju. Također, bilo bi korisno i dobro za demokratski proces u Bosni i Hercegovini - sklon različitim konsocijacijskim aranžmanima čiji je demokratski potencijal upitan i problematičan - da se konačno usaglase, prije svega zbog funkcionalnih razloga, simetrična rješenja izbora političkih predstavnika, koji se biraju na općim i lokalnim izborima, na različitim nivoima izvršne vlasti. Sve navedeno ima poseban značaj ako imamo u vidu da samo oni demokratski režimi vlasti u savremenoj i globaliziranoj politici, koji podjednako uvažavaju, pored političkih prava pojedinaca, i prava različitih identitetskih i manjinskih skupina, mogu da se razvijaju i dalje demokratski profiliraju u skladu sa temeljnim principima politika multikulturalizma i interkulturalizma. Bez toga atomizirana i neoliberalizirana demokratska politika, u osnovi, gubi svoju kohezivnu osnovu, solidarni karakter i temeljne atribute tolerancije.

Iako, naprimjer, Izborni zakon Bosne i Hercegovine, ali i dopune ovog izbornog zakona vrlo sadržajno reguliraju sferu nekih izbornih pravila, postoji opravdana potreba za donošenjem efikasnije regulative u određenim segmentima postojećeg izbornog zakonodavstva, što bi omogućilo, uzmimo, formiranje stabilnijih vlada na različitim nivoima vlasti, a da se pri tome ne ugroze interesi nacionalnih skupina. (Izborni zakon Bosne i Hercegovine, 2001; Zakon o izmjenama i dopunama Izbornog zakona Bosne i Hercegovine, 2016; Zakon o izmjenama Izbornog zakona Bosne i Hercegovine, 2020) Naime, bilo bi dobro podići i fiksirati izborni prag u spomenutoj izbornoj proceduri, u cilju efektivnog polariziranja stranačkog sistema i reprezentativnijeg predstavljanja građanskih interesa $u$ institucijama vlasti, što bi oslobodilo i rasteretilo demokratski proces od političke trgovine. Štaviše, nije uopće rijetkost da se ponekad ,... određuje 'prag' (pet procenata u Njemačkoj) da bi se sprečilo predstavljanje malih, često ekstremističkih partija. (Hejvud, 2004: 449) Tako da ovaj politički korektiv, recimo, itekako korespondira u sferi praktične politike sa supstancijalnim zahtjevima političkog funkcionalizma i stabilnosti, a, uz to, može efikasno politički proces štiti od političke trgovine i radikalizacije.

\section{Izborne preferencije i dominantni modeli glasanja: iskustva iz bosanskohercegovačke političke prakse}

Zastupljeni i etablirani modeli glasanja imaju presudan politički značaj i uticaj na zdravlje demokratskih režima vlasti, jer se reflektiraju na političku participaciju građanstva, izbornu politiku i preferencije birača. Političke 
stranke u demokratskim režimima vlasti na različite načine pokušavaju pridobiti podršku građanstva u političkoj borbi za osvajanje pozicija u državnoj vlasti. Obično to čine putem različitih oblika kampanje: kratkom kampanjom, koja traje od raspisivanja do datuma izbora, a političke partije se, u pravilu, najviše koncentriraju na ovaj oblik kampanje; dugom kampanjom koja počinje sa početkom izbornog procesa, a, u osnovi, vrlo je funkcionalna $i$ učinkovita; ili stalnom kampanjom gdje izborni proces i agitiranje, zapravo, nikad ne prestaje, tj. uvijek se vodi politička kampanja što može u političkoj praksi, u zavisnosti od političkog konteksta i partijskih aktera, imati različite implikacije. (Conley, 2001; Dal, 1999; Hague, Harrop, 2014; Hejvud, 2004; Renwick, 2010) Predizborne stranačke kampanje, politički marketing i svaki drugi uticaj na političko ponašanje birača ima za cilj da afirmativno utiče na političke preferencije građana, kako bi određena i zainteresirana stranačka reprezentacija mogla dobiti njihove glasove na izborima. Efekti predizborne kampanje često imaju kratkoročan i privremen karakter, jer se političke okolnosti stalnu mijenjaju tokom kratke izborne kampanje, pa to uglavnom može imati presudan uticaj na konačan izborni rezultat, što je posebno primjetno i vidljivo u bosanskohercegovačkom tranzicijskom režimu vlasti, u kojem se nerijetko vještački konstruiraju, vremenski tempiraju i vješto planiraju događaji i krize koji mogu imati homogenizacijski uticaj na biračko tijelo u predizbornom periodu.

Glasanje je najrelevantniji oblik političkog ponašanja građanstva u pluralističkim i demokratskim režimima vlasti u doba državnog policentrizma. U tom smislu moguće je konstatirati da ,... glas nije ništa drugo doli osnovni dio i funkcija svakoga političkog sustava, koji je katkada poznat i pod nazivom artikulacija interesa. Politolozi se već dugo sustavno bave tom funkcijom i njezinim različitim manifestacijama. No, pri tome se obično ograničavaju na situacije u kojima je jedina alternativa toj artikulaciji pomirenje sa situacijom ili ravnodušnost (a ne izlazak), dok ekonomisti odbacuju mogućnost da se nezadovoljni potrošač ponaša ikako drugačije osim da bude zastupljeno vjeran ili da počini otvorenu izdaju (u odnosu prema tvrtki s kojom je poslovao).“ (Hirschman, 2010: 23) Rezultati glasanja na izborima, u pravilu, ukazuju na stvarni odnos između građana, društva i politike. No, u postdejtonskoj Bosni i Hercegovini nije moguće pouzdano detektirati tu demokratsku vezu, jer je institut izbornog biranja u ovom političkom kontekstu reduciran, odnosno opterećen etničkim predstavljanjem, zbog čega bosanskohercegovački građani ne mogu na cijeloj državnoj teritoriji biti ravnopravni, niti mogu ostvariti punu političku participaciju. Štaviše, taj politički redukcionizam prepoznat 
je i od strane Evropskog suda za ljudska prava, na što je već ukazano, a koji je u različitim, ali povezanim predmetima donio nekoliko presuda, u kojima su neki segmenti bosanskohercegovačkog izbornog zakonodavstva markirani kao protudemokratski, jer imaju izražen segregirajući i majorizacijski karakter u sferi praktične i izborne politike.

Na političko ponašanje birača obično utiču kratkoročni i dugoročni faktori u praktičnoj politici. Oni najčešće imaju veći uticaj na glasanje i političke izbore građana čak i od provedenih predizbornih kampanja. Periodična participacija građana na izborima i glasanje birača imaju višestruki značaj za demokratsku politiku, legitimacijske procese u državi, ustavnoj politici i državnoj vlasti, zbog čega se u političkoj teoriji apostrofira i iznosi sljedeće: „Kada narod izražava svoju volju na izborima i glasanjima, on ustavno vezanoj organizaciji države daje legitimaciju koja se zahtijeva zbog ustava. To je intrakonstitucionalni proces u okvirima pozitivnog prava. No povrh toga narod pruža i jednu drugu, ekstrakonstitucionalnu legitimaciju, koja se ne odnosi na ustavno uređene državne organe nego na sam ustav.“ (Isensee, 2004: 159) U državama razvijene političke kulture većina građana još prije početka izborne kampanje donosi odluku o partijskim preferencijama i glasanju, zato što izbori, pored drugih normativnih značenja i funkcija, predstavljaju svojevrsno referendumsko izjašnjavanje o učinku prethodne vlasti, koju će građani prema zaslugama, $\mathrm{t} j$, $\mathrm{u}$ skladu sa datim i realiziranim političkim obećanjima nagraditi ili kazniti u novoj izbornoj utakmici. No, takva demokratska praksa nije izražena u postsocijalističkim i tranzicijskim državama, čija politička kultura još uvijek ima obilježja podaničke politike i kolektivizma, što je itekako moguće identificirati i prepoznati u bosanskohercegovačkoj praktičnoj politici, a posebno kada je u pitanju glasanje na izborima, gdje dominantan uticaj na preferencije građana i dalje ostvaruju tradicionalne kolektivističke skupine.

U takvim uvjetima birači se obično ne ponašaju uvijek kao racionalni politički akteri, zbog čega su nerijetko onemogućeni da naprave i odaberu pravi politički izbor, a posebno u uvjetima izrazito nerazvijene i niske političke kulture koja je, uz to, obilježena i začinjena političkom manipulacijom i demagogijom. Zbog toga neki pojedinci razvijaju antipolitički mentalitet, što je jako štetno za izborni proces i demokratsku vladavinu, pa se distanciraju od institucionalne politike i umjesto nje preferiraju vaninstitucionalne metode političkog aktiviteta. S tim u vezi, bilo bi smisleno, kada je u pitanju politički proces, zapitati se: „Zašto bi birač vodio brigu o glasanju ako mu se predlažu krajnje slične opcije, ako su u toku kampanjâ značajniji publicitet od rasprava, 
demagogija od razmišljanja, spektakularno od duboko suštinskog. Zašto od njega očekivati ozbiljnost, upornost, vrlinu, koju, jednom riječju, i politička klasa ismijava.“ (Bruckner, 1997: 73) Međutim, to još uvijek ne znači da je institucionalna politika postala irelevantna i da pluralističke i predstavničke demokratije ne mogu generirati nužne političke promjene za kojima čezne aktivno i zainteresirano građanstvo. Tako da je moguće i dalje detektirati, posebno u režimima vlasti sa razvijenom i participativnom političkom kulturom, ključne razloge koji utiču na rezultate izbora i izborne preferencije građana, a to su: trenutno stanje u ekonomiji i kvalitet socijalne egzistencije građana, zbog čega vlade, naprimjer, pred izbore pokušavaju proizvesti mentalitet 'dobrog osjećaja' kod građana; ugled partijskog vođe u javnosti; trenutni rejting političke partije; stil i djelotvornost predizborne kampanje, pa tako, recimo, bosanskohercegovačke etnonacionalne stranke, kao što je već apostrofirano, nerijetko konstruiraju vještačke političke krize i probleme u cilju homogenizacije biračkog tijela; kontinuirana tematska istraživanja javnog mnijenja kao pouzdan politički orijentir za političku viziju i obećanja; te, na kraju, uticaj i način izvještavanja mas-medija u sferi praktične politike. Iako se sve učestalije tvrdi da je čin glasanja birača na izborima postao personaliziran i da je izraz njihove lične i atomizirane političke volje, ipak na volju birača mogu uticati i različiti psihološki, socijalni, ekonomski i ideološki motivi. No, uticaj raznolikih faktora na izborne preferencije građana obično je promjenjiv i, u pravilu, zavisi od nivoa vlasti na kojem se provode izbori. Postoji nekoliko dominantnih modela glasanja, unutar kojih se objašnjava kako i na osnovu čega birači donose odluku o političkim preferencijama na izborima, a najznačajniji glasački modaliteti su: model partijske identifikacije, sociološki model, model racionalnog izbora i model dominantne ideologije. (prema: Hejvud, 2004) U nastavku će biti detaljnije ekspliciran uticaj navedenih modela glasanja na građane u postdejtonskoj bosanskohercegovačkoj politici.

Kod modela partijske identifikacije obično je izražen osjećaj pripadnosti nekoj političkoj partiji u pogledu glasanja na izborima, što se može povezati sa uticajem rane političke socijalizacije na politički izbor građana. No, kod građana sve više slabi partijska identifikacija zbog nezadovoljstva konvencionalnom politikom, političkim institucijama i nerealiziranim političkim obećanjima državne vlasti, ali i zbog atomiziranog uticaja neoliberalne globalizacije i ekspanzivnog uspona vaninstitucionalne politike. (Fejzić, 2017) Drugim riječima, moguće je konstatirati da slabljenje partijske identifikacije uzrokuje ,... smanjenje privrženosti ljudi političkim partijama. Kako odanost partiji opada, povećava se verovatnoća nepredvidljivosti ponašanja na 
izborima, što dovodi do veće neizvesnosti, a ponekad i do uspona novih partija ili pada starih. Opada ono što se smatra 'normalnom' podrškom i sve veći broj birača postaju 'plutajući' ili 'nestabilni'. Osnovni razlog slabljenja partijske identifikacije jeste širenje obrazovanja, povećanje geografske i društvene pokretljivosti i sve veća zavisnost od televizije kao izvora političkih informacija.“ (Hejvud, 2004: 454) Prema tome, u takvim uvjetima političke stranke ne mogu više presudno i dominantno uticati na političku participaciju građana i njihove političke izbore. Štaviše, takva praksa nije svojstvena samo liberalno-demokratskim režimima vlasti, već je sve više ukorijenjena i u postsocijalističkim režima vlasti, pa i u bosanskohercegovačkoj praktičnoj politici gdje su doduše etnonacionalne stranke i dalje vrlo uticajne, ali samo zato što reprezentiraju etnički identitet konstitutivnih naroda, a onda birači u ovom slučaju glasaju prema pravilima sociološkog modela.

Prema sociološkom modelu na glasanje presudno utiče društvena pripadnost građana, pa su u tom kontekstu važne klasne, etničke, rodne, vjerske, regionalne i zavičajne razlike i identiteti. Međutim, zbog nestajanja tradicionalne radničke klase i pojavljivanja neoburžoazije, kao i postindustrijskog transformiranja društva te slabljenja klasne identifikacije u razvijenim državama sa zrelom političkom kulturom, recimo, sve više slabi uticaj ovog glasačkog modela. No, u nekim tranzicijskim državama, poput Bosne i Hercegovine, koje imaju multinacionalnu strukturu, uveliko je izražen značaj etničke identifikacije građanstva jer je ukorijenjena u ustavnoj regulativi, pa se etnonacionalizam u takvim političkim kontekstima, uzmimo, promovirao u dominantan politički svjetonazor. (Ustav Bosne i Hercegovine, 1995) S druge strane, unutar modela racionalnog izbora glasanje se markira kao racionalan čin, tj. birači na osnovu ličnih interesa glasaju za određenu partiju. Dakle, u ovom slučaju glasanje je personalizirano i predstavlja sredstvo za postizanje ličnih ciljeva. Zbog slabljenja partijske i klasne identifikacije ovaj oblik glasanja postaje sve važniji u savremenoj politici. S tim u vezi, političke partije nastoje dati odgovore na probleme različitih ciljnih grupa u globaliziranoj politici. Međutim, ovaj model glasanja više je primjeren državama sa razvijenom političkom kulturom, dok se u tranzicijskim režimima vlasti, kao što je postdejtonski bosanskohercegovački režim vladavine, može pojaviti u izmijenjenom i atipičnom obliku, pa producira različite oblike političkog klijentelizma. (Merkel, 1999; Miler, 2017) Model dominantne ideologije odgovara kolektivističkim državama, jer u ovom slučaju na glasanje u značajnoj mjeri utiče ideološka manipulacija, populistički aktivitet i politička kontrola. (Miler, 2017) Prema tome, u ovom slučaju aktualiziran je uticaj aktera socijalizacije 
na glasanje pojedinaca, pri čemu se politička komunikacija usmjerava na vrlo manipulativan način. Uticaj dominantne ideologije na glasanje pojedinaca stvara politiku indiferentnu na političke promjene, kao npr. u slučaju komunizma i njegove privrženosti političkom monizmu - gdje protivnici tog režima nisu mogli lahko iznuditi političke promjene - a to je vidljivo i dalje kroz primjer kineskog tržišnog socijalizma ili, pak, neoliberalizma i njegove patološke privrženosti slobodnom tržištu i tržišnom fundamentalizmu.

Imajući navedeno u vidu, treba apostrofirati da je već odavno aktualizirana kriza umjerenih ideoloških svjetonazora, zbog čega sve veći uticaj na političku agendu u savremenim državama imaju radikalne političke ideologije, koje su otvorena prijetnja pacifističkoj i multikulturalnoj politici. Sa takvim rizičnim političkim uticajima suočene su već i neke tranzicijske države poput Bosne i Hercegovine, a posebno u kontekstu njihovog iskustava sa određenim oblicima religijskog fundamentalizma ili neoliberalnog kolonijalizma zasnovanog na nekritičkom implementiranju politike strukturalnog prilagođavanja. Ideološka radikalizacija praktične politike može destimulativno djelovati na politički proces i biti primarni uzrok pasivizacije građanstva, zbog čega u demokratskim državama ,... problem izražene političke apstinencije građana ima ekspanzivan karakter, odnosno permanentno raste populacija nezadovoljnih pojedinaca koji su razočarani i ne žele da participiraju u konvencionalnom demokratskom procesu.“ (Fejzić, 2017: 117) Tako da sve više raste i jača uticaj vaninstitucionalnih aktera u sferi praktične politike u savremenim državama.

\section{Zaključna razmatranja: \\ za građansko predstavljanje i pluralističku demokratiju}

U pluralističkim režimima vlasti, građani bi uvijek trebali imati osiguranu mogućnost da mogu na različite načine participirati u javnoj sferi. Također, interesi građana trebali bi uvijek biti neometano zastupljeni, u skladu sa pravilima političke jednakosti i narodnog suvereniteta, u političkoj praksi savremenih demokratija, zbog čega druge identitetske skupine ne bi trebale imati prednost u predstavljanju svojih političkih interesa, zato što se demokratija nužno zasniva na glasačkoj kompetenciji pojedinaca. Međutim, u praktičnoj politici tranzicijskih demokratija nerijetko se događa demokratski paradoks, a takva praksa prisutna je u Bosni i Hercegovini, pa kolektivističke grupe, kao što su etničke zajednice u multinacionalnim državama, imaju privilegiran status u izbornom zakonodavstvu i u pogledu političkog predstavljanja. Takva 
koncepcija politike nije kompatibilna sa temeljnim načelima pluralističke demokratije, zbog čega je potrebno tragati za efikasnijim političkim rješenjima koja će moći građanima osigurati politički integritet.

\section{Bibliografija}

Attali, Jacques (2008). Kratka povijest budućnosti. Meandar media. Zagreb.

Ballestrem, Carl (1998). Narodni suverenitet u ustavnoj državi. Politička misao. Vol XXXV (br. III), str. 64-77.

Bieber, Florian (2006). Post-war Bosnia: ethnicity, inequality and public sector governance. Palgrave Macmillan, UNRISD. New York.

Bruckner, Pascal (1997). Sjeta demokratije. Zid. Sarajevo.

Conley, Patricia H. (2001). Presidential Mandates: How Elections Shape the National Agen$d a$. University of Chicago Press. Chicago.

Crouch, Colin (2007). Postdemokracija. Izvori. Zagreb.

Dal, Robert (1999). Demokratija i njeni kritičari. CID. Podgorica.

Fejzić, Elvis. (2016). Nedostaci i ograničenja referendumske demokratije. Godišnjak BZK Preporod. Vol. XVI (br. XVI), str. 17-32.

Fejzić, Elvis. (2017). Vlast, građanstvo i sloboda: od političke kontingencije do transformacije političkog. Pregled. Vol. LVIII (br. III), str. 101-118.

Franklin, Mark N.; Wlezien, Christopher; ed. (2002). The Future of Election Studies. Pergamon - An imprint of Elsevier Science. Oxford.

Hague, Rod; Harrop, Martin (2014). Uporedna vladavina i politika: uvod. Fakultet političkih nauka Univerziteta u Beogradu. Beograd.

Hejvud, Endru (2004). Politika. Clio. Beograd.

Hirschman, Albert O. (2010). Izlazak, glas i lojalnost: reakcije na propadanje tvrtki, organizacija i država. Fakultet političkih znanosti Sveučilišta u Zagrebu. Zagreb.

Isensee, Josef (2004). Država, ustav, demokracija. Politička kultura. Zagreb.

Izborni zakon Bosne i Hercegovine, Službeni glasnik BiH (br. 23/01 od 19. 9. 2001. godine), Sarajevo, 2001.

Kaningam, Frenk (2003). Teorije demokratije. Filip Višnjić. Beograd.

Kulenović, Željka (2005). Politika i novac: financiranje političkih stranaka i izbornih kampanja. TIM press. Zagreb.

Leigh, David; Vulliamy, Ed (1997). Prljavština: Korupcija u parlamentu. Naklada Zadro. Zagreb.

Merkel, Wolfgang (1999). Teorije transformacije: demokratska konsolidacija postautoritarnih društava. Politička misao. Vol. XXXVI (br. III), str. 121-150.

Miler, Jan-Verner (2017). Šta je populizam?. Peščanik. Beograd.

Ofe, Klaus (1999). Modernost i država: Istok, Zapad. Filip Višnjić. Beograd.

Prelot, Marcel (2002). Političke institucije: opća teorija političkih institucija. Politička kultura. Zagreb.

Renwick, Alan (2010). The Politics of Electoral Reform: Changing the Rules of Democracy. Cambridge University Press. Cambridge.

Rouz-Ejkerman, Sjuzan (2007). Korupcija i vlast: uzroci, posledice i reforma. Službeni glasnik. Beograd.

Šarčević, Edin (2009). Dejtonski ustav: karakteristike i karakteristični problemi. Fondacija Konrad Adenauer, e.v. Predstavništvo u Bosni i Hercegovini. Sarajevo. 
Ustav Bosne i Hercegovine, OHR - Office of the High Representative, Sarajevo, 1995.

Vorländer, Hans (2001). Supremacija ustava: o odnosu napetosti između demokracije i konstitucionalizma. Politička misao. Vol. XXXVIII (br. I), str. 26-35.

Zakon o finansiranju političkih stranaka, Službeni glasnik BiH (br. 95/12 od 27. 11. 2012. godine), Sarajevo, 2012.

Zakon o izmjenama i dopunama Izbornog zakona Bosne i Hercegovine, Službeni glasnik BiH (br. 31/16 od 29. 4. 2016. godine), Sarajevo, 2016.

Zakon o izmjenama i dopunama Zakona o finansiranju političkih stranaka, Službeni glasnik $\mathrm{BiH}$ (br. 41/16 od 3. 6. 2016. godine), Sarajevo, 2016.

Zakon o izmjenama Izbornog zakona Bosne i Hercegovine, Službeni glasnik BiH (br. 41/20 od 10. 7. 2020. godine), Sarajevo, 2020.

\section{Electoral Legislation in Bosnia and Herzegovina: Problems, Needs and Opportunities}

\section{Concluding remarks}

In pluralistic regimes of government, citizens should always be provided with the opportunity to participate in various ways in the public sphere. Also, the interests of citizens should always be represented without hindrance in political practice of modern democracies, in accordance with the rules of political equality and people's sovereignty, which is why other identity groups should not have priority in representing their political interests, because democracy is necessarily based on voting competence of individuals. However, in the practical politics of transitional democracies, a democratic paradox often occurs, and such a practice is present in Bosnia and Herzegovina, so collectivist groups, such as ethnic communities in multinational states, have a privileged status in electoral legislation and political representation. Such a conception of politics is not compatible with the fundamental principles of pluralistic democracy, which is why it is necessary to look for more efficient political solutions that will be able to ensure political integrity for citizens. 